\title{
What Has Kinshasa to Do with Athens? Methodological Perspectives on Theology and Social Science in Search for a Political Theology
}

\author{
Elias Kifon Bongmba
}

"What has Kinshasa to do with Athens?" is a quintessential African question that has its origins in the query by North African theologian Tertullian (Quintus Septimius Florend Tertullianus): "What has Athens to do with Jerusalem?" (De Praescriptione vii). ${ }^{1}$ The African version refers to the robust debate on theological method between members of the Kinshasa School of Theology that pitted two faculty members against each other: Tharcisse Tshibangu, the Dean of the Faculty, who championed a theology that would draw its arguments mainly from the African cultural, religious, and intellectual world to make it African theology, and A. Vanneste, on the Kinshasa faculty at the time, who called for a universal catholic theology because an African theology limited only to African thought and culture would be isolationist. Today's question - what does Kinshasa have to do with Athens? - calls for a different analysis that would still involve using African sources; but I must add that another dimension that requires urgent attention if theological thinking in Africa is going proceed from a broad platform is the relationship between theology and the social sciences.

I argue that theological scholarship in Africa should maintain a robust dialogue with the social sciences in order to forge a new and creative discourse on political theology. ${ }^{2}$ I begin with a brief review of the debate between Abongkhiameghe Orobator and Charles Nyamiti on methodology to demonstrate the imperative of such a dialogue. ${ }^{3}$ I then present arguments supporting my view

1 This chapter was presented at the conference, African Lived Christianity - Faith, Ritual and Power, at Lund University, March 16-18, 2016. I thank the Lund Mission Society for providing the funds for me to participate in this conference of the Lived Christianity Project at Lund University. I thank the Board of Directors of the Mission Society for the warm hospitality they gave us when we met at Lund University. I also thank Mika Vähäkangas and Karen Lauterbach for their wonderful insights and suggestions.

2 Elias K. Bongmba, "Interdisciplinary and Transdisciplinarity in African Studies," Religion and Theology, 21, no. 3-4 (2014), 218-250.

3 Abongkhiameghe E. Orobator, From Crisis to Kairos: The Mission of the Church in the Time of HIV/AIDS, Refugees and Poverty (Nairobi: Pauliness Publications, 2005); Charles Nyamiti, 
that such a position is necessary to articulate a progressive political theology in the African context. I do not seek to undermine disciplinary boundaries, merely to argue, firstly, that disciplinary distinctiveness offers only a single perspective, reminding scholars of the claim by Johannes Fabian that when driven solely by its own perspective, anthropology (and here I must add, theology) is a Grenzwissenschaft. ${ }^{4}$ A critical multidisciplinary dialogue is necessary for many who still live with Africa, if I can borrow an expression from Jan Vansina. $^{5}$

Second, interdisciplinary dialogue is necessary because the place and status of theology has been a hotly contested issue. Modern developments in the social sciences, especially in anthropology, history, political science, and sociology, have opened up the study of Africa by introducing theoretical innovations. ${ }^{6}$ This development has led to the denigration of theology which some Africanists have, at best, treated as an arm of the missionary movement or, at worst, largely as a confessional discipline. In the excellent book, Africa and the Disciplines (1993), for example, contributors offered brilliant insights from a range of disciplines except theology. ${ }^{7}$

Third, it would be presumptuous to call the human and social sciences partners, but it is the case that theology and the social sciences serve each other's interests as scholars seek to understand and illuminate reality. The mythopoesis that has developed over the centuries, the norms of articulation, the theories, and the intellectual values that have been used to shape our understanding of African communities therefore invite careful critical dialogue between theologians and social scientists.

In the first section, I introduce the debate on methodology in African theology. I then discuss two proposals for political theology from Emmanuel Katongole and Nimi Wariboko, arguing that their insightful theological perspectives should be strengthened by perspectives from the social sciences to have a balanced view of political theology in the African context. I make that case by

Some Contemporary Models of African Ecclesiology: A Critical Assessment in the Light of Biblical and Church Teaching, Studies in African Christian Theology, Vol 3 (Nairobi: Catholic University of East Africa, 2007).

4 Johannes Fabian, Time and the Other: How Anthropology Makes its Object (New York: Columbia University Press, 1983).

5 Jan Vansina, Living with Africa (Madison: The University of Wisconsin Press, 1994).

6 See V.Y. Mudimbe, The Invention of Africa: Gnosis, Philosophy, and the Order of Knowledge (Bloomington: Indiana University Press, 1988); see also V.Y. Mudimbe, The Idea of Africa (Bloomington: Indiana University Press, 1994).

7 Robert Bates, V.Y. Mudimbe, and Jean O'Barr, Africa and the Disciplines: Contributions of Research in Africa to the Social Sciences and Humanities (Chicago: University of Chicago Press, 1993). 
suggesting and discussing a dialectical view of the notion of sovereignty as a background to political theology. I should also state that in advancing an argument for a conceptualized notion of sovereignty in political theology, one must recognize the European influence on such ideas, yet also recognize debates that have called into question the influence that Western models of sovereignty have had on African understanding of politics. ${ }^{8}$ Nor can one ignore criticism from scholars that discourses that have focused on state failure in Africa have been seen by some African scholars as problematic because many African states have acted in the face of, and continue to find ways of responding to, state collapse. ${ }^{9}$ Furthermore, while I address the idea of sovereignty as formulated in the work of Carl Schmitt, I do not assume that Schmitt's perspective is the only valid view of sovereignty. ${ }^{10}$ I am sure that one could and should rework African conceptions of sovereignty based on African political systems.

\section{Orobator and Nyamiti on Methodology}

Nigerian theologian, Agbonkhianmeghe E. Orobator, and Tanzanian theologian, Charles Nyamiti, have taken positions that illuminate the debate between theology and the social sciences. To begin with, Orobator in From Crisis to Kai$r{ }^{11}$ has argued that much of the literature on the church in Africa has ignored the social context because theologians have used ecclesial models developed elsewhere and employed an "inculturation devoid of any immediately recognizable referent in a particular social context" to ground the church in "static cultural symbols."12 Orobator calls for greater social analysis in order for scholars to present a more robust picture of the church, rather than their depending on theological analysis alone.

Orobator proposes an ethnographic approach to studying HIV/AIDS, refugees, and poverty in Africa to articulate a contextual theology that engages the "complex issues of social concern."13 He studies the church in light of Lumen Gentium (the Dogmatic Constitution of the Church [1964] which describes a settled church and its evangelical and proselytizing role) and Guadium et Spes

8 Tobias Hagmann and Didier Pélcard, eds., Negotiating Statehood: Dynamics of Power and Domination in Africa, (Malden, MA: Wiley Blackwell, 2010).

$9 \quad$ Hagmann and Pélcard, Negotiating Statehood, 2010, 2; See James Ferguson, Global Shadows: Africa in the Neoliberal World Order (Durham, NC: Duke University Press, 2006).

10 See also Jacques Maritain, Man and State (Chicago: University of Chicago Press, 1951).

11 Orobator, From Crisis to Kairos.

12 Ibid., 13.

13 Ibid., 15, emphasis in the original. 
(the Pastoral Constitution of the Church in the Modern World [1965] which invites a conscious wrestling with the realities of the times, especially in a period of great uncertainty) in dialogue with Ecclesia in Africa ${ }^{14}$ to provide a theoretical perspective on how to move from crisis to Kairos (the present moment in which the church is called to address many social issues). Orobator promotes fieldwork and participant observation, and emphasizes verstehen that calls for the use of both qualitative and quantitative research approaches. He carried out his studies in Eastern Africa where he interacted with people living with AIDS, refugees, and poverty. An engagement in the social context in Keya enabled him to observe, gather data, and conduct unstructured interviews during which he asked open-ended questions in formal and informal settings. These sessions varied in length from a few minutes to a little over an hour. The goal was to hear the people on their own terms, and practice what Andrea Fontana and James F. Frey describe as a "human to human" approach. ${ }^{15}$

Charles Nyamiti argues that Orobator accuses African scholars of imposing foreign ecclesiologies but, in doing so, Orobator himself engages in a translation which ignores the social context in Africa. ${ }^{16}$ Nyamiti rejects Orobator's claim that African theologians describe the church with static symbols that have no meaning in the social context, claiming that Orobator abandons the hard fought gains made in the theology of inculturation (theological analysis that has taken into consideration African cultural values and context) in favor of the approach of Latin American liberation theologians. Furthermore, Nyamiti rejects Orobator's claims that African ecclesiologies are imported and argues that because African ecclesiology is also rooted in the notion of the family, scholars think of the church that way and therefore include a broad social context; consequently, one cannot dismiss inculturation or claim, as Orobator does, that it has no bearing on the crisis churches in Africa face today. Orobator therefore is inconsistent because he uses ecclesiological paradigms, such as sacramental and communal perspectives, that have been developed outside Africa at the expense of locally developed approaches, such as ancestral theological approaches. ${ }^{17}$ By dismissing a "tripartite ancestral koinonia ecclesiology" proposed by Nyamiti as an oddity because it focuses on arcane ideas, Orobator ignores African cultural realities such as ancestral

\footnotetext{
14 John Paul II, Ecclesia in Africa, (Post Synodical Apostolic Exhortation) (Nairobi: Paulines Publications, 1995).

15 See Andrea Fontana, "The Interview: From Structured Questions to Negotiated Text," in Handbook of Qualitative Research, eds. Norman K. Denzin and Yvonna S. Lincoln (Los Angeles: Sage Publishers, 2005), 654

16 Nyamiti, Models of African Ecclesiology, 148.

17 Ibid., 158.
} 
thought that stresses love of life, morality, and the social issues that Orobator addresses.

Furthermore, Nyamiti argues that Orobator's reductionist approach subordinates the mission of the church to its involvement with social wellbeing, privileging the secularization of the meaning and work of the church, and ignoring or conflating the supernatural and terrestrial dimensions of the mission of the church. He claims that Orobator's approach is superficial because he has limited himself to the social sciences and ignored metaphysical approaches to theology, absolutizing his methodology and rejecting doctrinal and missional approaches to theological views of the church..$^{18}$ Nyamiti also argues that the images Orobator uses to describe the church, such as healer, Mother, advocate, and pilgrim community of the poor, require a hermeneutics of incarnation, yet his originality is limited by a superficial theological perspective which ignores the nature of the church and its traditional traits, such as catholicity, oneness, and apostolicity. Orobator fails to distinguish the church from a civil state. ${ }^{19}$

In a later essay, Orobator called for a contextual approach because "theology does not operate outside the boundaries of our ordinary human experience."20 The raw materials for theology, God's self-revelation to humanity, are experienced contextually. Theology is incarnational, grounded on the idea of the kenosis, (self-emptying) of Jesus who took on human flesh and lived and worked among people in specific contexts. ${ }^{21}$ Theology in Africa addresses the "African reality in the light of Christian faith."22 Inculturation takes into account the religious thoughts of the people and stresses the dynamic encounter between religious ideas and culture in understanding God. ${ }^{23}$ This dialogical approach between African indigenous religions and Christianity has previously been referred to as "adaptation" but today the term "inculturation" is preferred because it reflects a rootedness of the Christian faith in a local culture. ${ }^{24}$ Orobator indicates that contextualization is correlative because it discloses and explicates the impact of faith on economic and political matters and vice versa. According to Orobator, "the theologian is a member of a faith community,

\footnotetext{
$18 \quad$ Ibid., 167.

19 Ibid., 173-174.

20 Agbonkhianmeghe E. Orobator, "Contextual Theological Methodologies" in African Theology on the Way: Current Conversations, ed. Diane Stinton (London: SPCK, 2010), 3.

21 Ibid., 5 .

22 Ibid., 6.

23 Ibid., 7.

24 Laurenti Magesa, "African Christian Spirituality" in African Theology on the Way: Current conversations, ed. Diane Stinton (London: SPCK, 2010), 74.
} 
who strives to understand its 'joys and hopes, grief and anguish' in light of God's self-revelation." ${ }^{25}$ Contextual theology is interdisciplinary. Using the example of HIV/AIDS he argues that the pandemic must be understood in the social, economic, political, religious, and cultural context in which the epidemic has thrived and multiplied. ${ }^{26}$

Nyamiti insists correctly that it would be a great disservice to the theological enterprise to ignore the rich theological data that has accumulated over the years from different sources: biblical texts, tradition, the Magisterium, philosophical and ethical interpretations, and reconstructions forming the cultural and liberation theological discourses which have grown in Africa. There is a mystery about the faith community and a cultural grounding that includes the religious world of Africans that must not be overlooked as arcane, because these remain part of a mythopoetic world that requires a rereading in different contexts and time. This underlying religio-ethical architectonic substratum provides the intellectual grounding for understanding the data presented to us on a daily basis. Therefore, the positions articulated by Orobator and Nyamiti reinforce the need for interdisciplinarity in theology studies in the African context.

Nyamiti notes that the positive aspects of Orobator's enterprise include calling attention to crisis in Africa - wherein social science methodology offers important insights - and also the centrality Orobator accords the incarnation of the mission of the church, which he sees as the body of Christ. Orobator's work includes all the positive elements of liberation theology articulated by the Pontifical Commission on the Bible: awareness that the God who saves is present in suffering; affirmation of the communal dimension of faith in Africa; articulation of the urgency of liberation, justice and love; and a fresh reading of the Bible in the context of contemporary African crises. In the next section, I argue that in moving beyond methodology, a compelling case for critical dialogue is necessary in order for theologians to articulate a critical and engaging perspective on theology and politics.

\section{Vibrant Political Theology Requires Dialogue between Theology and Social Science}

The Orobator and Nyamiti debate reflects two complementary positions on theology and Geisteswissenschaften (which initially in the German academy

\footnotetext{
25 Orobator, Contextual Theological Methodologies, 8.

26 Elias K. Bongmba, Facing a Pandemic: The African Church and Crisis of AIDs (Waco: Baylor University Press, 2007).
} 
included the social sciences), but to which today we must specifically add the social sciences. ${ }^{27}$ Historically, theological studies of politics were championed by liberation theologians in Southern Africa who battled white racist regimes. In the mid-199os, Jesse Mugambi and Charles Villa-Vicencio spelled out a theology of reconstruction and appealed directly to structural issues, nation building, and human rights. This was a timely argument in the post-cold war era where there was political and economic stagnation and a mounting abuse of human rights. It is in light of the need for a dialogical approach that I engaged in a dialogue with the social sciences and theology in The Dialectics of Transformation in Africa. ${ }^{28}$ The way forward calls for a theological engagement that takes seriously inculturation, transformation, and human dignity. This is a task that requires serious engagement with the social sciences and critical theological analysis, which must pay attention to the global as well as local historical traditions that have shaped the Christianity, its sacred texts, symbols, and moral ethos. This dialogical approach invites research on countless fronts and to ignore critical interdisciplinary dialogue would be tantamount to a scholarly dereliction of duty. Scholars would do well to avoid marginalizing discipline-oriented research that does not come from their own discipline, as the need for an interdisciplinary dialogue and approach to understanding religion and the religious experience in Africa remains an important intellectual priority. The social sciences, and the methodological approach which privileges data collection through fieldwork, would provide theologians with specific information on different aspects of church life before they address theological concerns. Before we explore that, however, I will discuss the political theology of Emmanuel Katongole, which emphasizes local Christian narratives and practices, to further make the case that for robust interdisciplinary dialogue.

\section{Emmanuel Katongole on Political Theology}

Emmanuel Katongole has presented a political theology in The Sacrifice of Africa that is grounded on the motif of lament and narrative. ${ }^{29}$ Drawing from Adam Hochschild's analysis in King Leopold's Ghost, Katongole laments the

27 See Rudolf A. Makkreel and Frithjof Rodei, Selected Works Volume 1: Introduction to the Human Sciences (Princeton, NJ: Princeton University Press, 1991), 6.

28 Elias K. Bongmba, The Dialectics of Transformation in Africa (New York: Palgrave Macmillan, 2006).

29 I have discussed this account elsewhere. See Elias K. Bongmba, "Lament and Narrative: A Review of Emmanuel Katongole's The Sacrifice of Africa," Modern Theology 30, no. 2 (2014), 403-407. 
exploitive politics and violence in Africa that continues to sacrifice the continent, and argues that African churches should shift from a social ethics that draws its analysis from the failure of political culture, the problems of structural reforms, discourse on governance, and prescriptions from the liberal global perspective. Katongole proposes an approach to political theology that stresses narrative to redirect the conversation away from a heavy emphasis on evangelization and spirituality, development and relief, or the overemphasis of mediation, advocacy, and reconciliation. These approaches have failed and Katongole argues that social ethics requires a clear focus on stories that reflect the histories and experiences of Africans because this will open up an analysis that goes beyond the focus on leadership failure and calls for structural changes. Africa needs to "discover the founding story of modern Africa, within which nation building and the nation-state project are inscribed. Only by attending to this story and displaying its performance can a new framework for doing Christian social ethics in Africa emerge."30 Katongole joins many African scholars who have called for a clear African voice in the disciplines; what is different here is that he frames his call in language that invites African theologians to explore the mythopoetic world of their societies as well as the things that have created crisis in the postcolonial state. ${ }^{31}$

In the second section of the book, Katongole offers two theoretical perspectives and practices to ground his argument. First, he lauds "the madness (more appropriately, the boldness) of Thomas Sankara" in Burkina Faso, whose broad reforms recognized the divisive and class-oriented neocolonial exploitation of the people. Sankara rejected the inevitability of poverty and called on the people to build their self-image and develop the self-confidence to promote local economic ideals. ${ }^{32}$ Second, Jean Marc Ela challenged the ecclesial community in Africa to imagine a "different world right here," and recognize that Africa was an empire of hunger because conspicuous consumption had made African leaders develop a desire for the West and its goods and ignore local needs in education and healthcare.

In the third and last section of the book, Katongole develops a model for political theology that is drawn from concrete examples (gathered from fieldwork) of a new spirit of activism that promotes reconciliation, peacebuilding, and human dignity. Bishop Paried Taban has created the Kuron Peace Village to offer an alternative space where there would be no discrimination in Sudan.

3o Emmanuel Katongole, The Sacrifice of Africa: A Political Theology for Africa (Grand Rapids: William B. Eerdmans Publishing Company, 2011).

$31 \quad$ Ibid., $10-20$.

32 Ibid., 93 . 
Angelina Atyam's daughter was kidnapped and raped by the forces of Joseph Kony and, by the time she was able to escape and return, she had given birth to two boys. Yet Atyam has called for forgiveness and reconciliation, constructing a new future that will avoid violence or revenge. Maggy Barankitse started Maison Shalom in Burundi to protect and save Hutu children from being killed by rebel soldiers. This place became one of love and forgiveness. Katongole calls on Africans to become fired up and stubborn, to move beyond the social limits on religion, and embrace a revolutionary love and spirituality. ${ }^{33}$ The examples Katongole discusses are not unique because Uganda has had an overabundance of faith-based and non-governmental organizations engaged in relief and reconciliation. China Scherz has argued that humanitarianism, development, and charity in the region are all distinct practices, which build both the aid workers and the recipients of aid into moral subjects. ${ }^{34}$ Scherz's studies of ChildHope and Mercy House in Uganda demonstrates how these two organizations engage in ethical practices as they relate to their clients and donors, and in analyzing these relations Scherz offers a new perspective on sustainable development and charity, discussed by Katangole.

To sharpen attention on the need for a vital political theology that also draws from a broad dialogue with the social sciences, in the following section I discuss another example, this one provided by Nimi Wariboko.

\section{Nimi Wariboko on Pentecostal Theology in Africa}

In his Nigerian Pentecostalism (NP), Nimi Wariboko offers a fascinating interdisciplinary discussion of political theology. Wariboko's point of departure is Paul Tillich's views of power against the backdrop of the historicity of the political (and ecclesial) community and its anticipation of the new. ${ }^{35}$ He studies politics under the rubric of spiritual presence as a context where the Tillichian "ultimate concerns" are experienced and expressed in love, justice, and the Protestant principle. Tillich refers broadly to Protestantism "as a special historical embodiment of a universally significant principle", which could be

33 Emmanuel Katongole, The Sacrifice, 193-196; See also Emmanuel Kantogole, Born From Lament: The Theology and Politics of Hope in Africa (Grand Rapids: William B. Eerdmans, 2017)

34 See also China Scherz, Having People, Having Heart: Charity, Sustainable Development, and Problems of Dependence in Central Uganda (Chicago: University of Chicago Press, 2014). I thank Karen Lauterbach for bringing this wonderful study to my attention.

35 Nimi Wariboko, Nigerian Pentecostalism (Rochester: University of Rochester Press, 2014), 148. 
found in all religions but, in a more specific way, in Protestant discourses that reject infallibility. ${ }^{36}$ According to Wariboko, spiritual presence is an enabling modality that enhances moral disposition. ${ }^{37}$ It is an engagement that recognizes the Spirit as well as the demonic; hence, his analysis emphasizes social relations characterized by domination and the imposition of suffering. ${ }^{38}$ Wariboko pushes beyond the entitative and non-entitative dimension to include the "political as the human organizing of agonistic power in society through practices." Such practices are found in every society and are determinative of the ontological conditions of persons. ${ }^{39}$ Ontologically, politics informs social practices which, following Achille Mbembe, Wariboko names necropolitics, a term that Mbembe has used to describe political practices that use the notion of sovereignty to determine who lives and who dies in the postcolony. The key to understanding these dimensions of power in Pentecostal spirituality lies in the power of the Spirit who counters the negative dimensions of power. Political spirituality engages systems of power by inscribing the presence of the divine who sees and watches over everything, both at the household and national levels. Therefore, one way of resisting the political network of power today "is the countergeneration of collective power ... actualized when members of a corporate body act in concert ... It happens when believers stand up together and act for their common good [the good of all members of the community]." ${ }^{40}$ This action might include some of the things Pentecostal Christians do, such as coming together to pray all night.

Wariboko claims that dominant and corrupt leaders have abused the notion of sovereignty in political theology in the context of Africa. It is a socio-political context in which "Satan and his cohorts, and God are in competition over human lives and nations. Pentecostals see themselves as securing God's sovereignty over their lives and their nations." ${ }^{\text {41 }} \mathrm{He}$ points out rightly that this is what Ruth Marshal reported in Political Spiritualities. ${ }^{42}$ Spiritual warfare involves raging with forces which Achille Mbembe describes as "the generalized instrumentalization of human existence and the material destruction of

$36 \quad$ Paul Tillich, The Protestant Era (Chicago: University of Chicago Press, 1948), vii.

37 Wariboko, Nigerian Pentecostalism, 148-149.

38 Ogbu U. Kalu, African Pentecostalism (Oxford: Oxford University Press, 1998), 199; Ruth Marshall-Fratani, "Mediating the Global and Local in Nigerian Pentecostalism," Journal of Religion in Africa 28, no. 3 (1998): 278-315.

39 Wariboko, Nigerian Pentecostalism, 151.

$40 \quad$ Ibid., 153.

$41 \quad$ Ibid., 154.

42 Ruth Marshall, Political Spiritualties: The Pentecostal Revolution in Nigeria (Chicago: University of Chicago Press, 2009), p. 236. 
human bodies and populations."43 Therefore, Wariboko sees in politics a warfare in which the grace of God and the power of the Spirit counter the negative situation and imagine an alternative social vision, something common to many ecclesial communities. In my view, this is a rather strong characterization because I continue to see politics as the science, art, and practice of enabling, leading, and governing a political community to function, thrive, and nurture the common good. Given the imagery of spiritual warfare, Wariboko sees

political spirituality as a way of claiming a stake in a hostile world, imposing one's acquired sovereignty (from Jesus, the superpower) on daily events, as a pattern of defending one's turf in the agonistic power exchanges to safeguard one's being and to significantly and meaningfully elevate one's level of flourishment, as a form of warfare. ${ }^{44}$

In Chapter 7, Wariboko discusses politics in Nigeria, focusing on miracles, sovereignty, and the idea of community. Wariboko rejects Marshall's view that NP has no prospects of creating a political community that responds to the need of Nigerians because Pentecostalism is fractured, focuses on miracles, and rejects the idea of sovereignty, which has held people and communities together. He suggests, on the contrary, that NP offers

a community of a new type, proper to the forms of diffuse individualized, monoisopmorphic forms of connectedness in our globalized world. Thus, with respect to structures of authority or forms of collective association or action, the decisive factor remains the spiritual state of the individual. ${ }^{45}$

Wariboko, who approaches the topic from a normative perspective, rejects Marshall's analysis of social reality because she focuses on the sovereign head of a political community and ignores the abuses of that system. He also rejects the view that Pentecostalism has not created the kind of effective institutions that could address political problems, charging that Marshall's formulation is clouded by a narrow view of morality instead of a broad view of ethics that could help people understand sovereignty, which Marshal has misinterpreted

\footnotetext{
43 Achille Mbembe, "Necropolitics," Public Culture 15, no. 1 (2003), 11-140.

44 Wariboko, Nigerian Pentecostalism, 158. Karen Lauterbach has pointed out that this stresses an individualistic approach. Personal communication.

45 Ruth Marshall, Political Spiritualities, 208.
} 
as a single political leader. Wariboko insists that sovereignty in Pentecostalism should be understood through repeated actions, where "norms, virtues of good governance and sustainable polis are cited and recited to produce ... the sovereignty it must refer to." ${ }^{36}$ The normative principles Wariboko elucidates here may not reflect the Nigerian Pentecostal and political scene. Furthermore, although the distinctions between a moral community and the political community are not made clear, there is an opening at this point in Wariboko's argument to nuance the conceptualization of sovereignty; this he does not do because he is interested in the ethical practices that are carried out in the application of Pentecostal spirituality. Wariboko goes on to discuss miracles as the birth of the new. Miracles are manifestations of the excesses of grace, and he places miracles and the prosperity gospel in the context of structural spirituality, arguing they can be seen as social practices and expressions of lived spirituality.

While Wariboko offers an astute and compelling view of ethics, I do not think one can dismiss Marshall's view that Pentecostalism is not able to develop a viable political community (and one might add a political theology) because it lacks the notion of sovereignty. Given the practices of governance in the postcolony, especially as we have seen in Africa, this is a reasonable concern. One can also not overlook the fact that Schmitt's view of politics and sovereignty causes disquiet among contemporary thinkers because Schmitt stressed the theological roots of power which at the time he wrote had already been secularized, even though the image domination linked to the divine rights gave many in Europe that authoritarian decision-making because of the powers of rulers remained in place. ${ }^{47}$ Schmitt also argued that even jurisprudence had an exception, which he described as a miracle to underscore the theological roots of the idea of the political. Schmitt offered a grim picture of the political when he painted a picture of social crises and differences as warfare between friends and enemies in which one seeks to eliminate one's enemy. ${ }^{48}$ Schmitt's political theology suggested that to live without violence would be to live in an apolitical society. ${ }^{49}$ This inevitability of conflict and violence made Schmitt postulate the idea of the sovereign who makes the decisions in cases of emergencies and can do so because, as sovereign, that person is not subjected to the juridical process as others are.$^{50}$ One can appreciate Schmitt's

$46 \quad$ Wariboko, Nigerian Pentecostalism, 180.

47 Carl Schmitt, The Concept of the Political, (Chicago: University of Chicago Press, 1996) p. 36

48 Ibid., 27-28.

49 See further discussion in Heinrich Meier, Carl Schmitt and Leo Strauss: The Hidden Dialogue, trans. J. Harvey Lomaz (Chicago: University of Chicago Press, 1995), $17 \mathrm{ff}$.

5o Schmitt, The Concept of the Political, 35 . 
somewhat limited historical interpretation, especially if one considers that he published his work during the era of the Weimer Republic.

The response to Schmitt has moved away from the idea of the sovereign "One" to focus variously on the God who liberates through Jesus, through theologies of hope, and liberation theologies in a global context that have fought against dictatorships, contra Schmitt's view that the world consists of two opponents who must struggle to overcome one another. ${ }^{51}$ Wariboko joins the chorus that rejects the notion of the sovereign leader by arguing that scholars should rework the wisdom (the broad teachings of the Christian church) which Pentecostalism has inherited concerning community, sovereignty, and miracles but, more importantly, rethink them in the light of virtue ethics. ${ }^{52}$ I think there is reason to deploy part of this strategy, but political theology cannot be grounded on that alone. Additionally, Wariboko rejects spirituality as an aesthetic way of life that offers messianic nows that lack a unity of life and he calls instead for an approach that has a discernible telos that can generate commitment and responsibility for the future. The theology he proposes "includes shifting the line of discourse from an analytical-political science emphasis on sovereignty as an exception or on the inability of miracles to ground a polis to that of practices of and virtues for creating and sustaining a Pentecostal form of community" ${ }^{53}$ What Wariboko means is that, rather than constructing a political theology based on the idea of a sovereign leader, certain important beliefs and practices in Pentecostal teachings, such as grace, community, virtue ethics, and spirituality, can serve as the conditions for creating a polity of virtue that would enable actors fulfill their obligations to the state and its people.

On the specific question of sovereignty, Wariboko argues that, in addition to social practices and beliefs, charismatic eruptions also contribute to the cultivation of virtues. The charismatics serve to counterbalance "established

$51 \quad$ See Johann Baptist Metz, Theology of the World (New York: Seabury Press, 1973). Political theology is experiencing a renaissance today in the academy with many single authored books and edited volumes. See for example: Alister Kee, ed. A Reader in Political Theology (London: SCM, 1977); Alister Kee, ed., The Scope of Political Theology (London: scm Press, 1978); Hent de Vries and Lawrence E. Sullivan, Political Theologies: Public Religions in a Post-Secular World (New York: Fordham University Press, 2006); Peter Scott and Willian T. Cavanaugh, The Blackwell Companion to Political Theology, (Malden, MA:Wiley-Blackwell, 2006); Michael Kirwin, Political Theology: An Introduction (Minneapolis: Fortress Press, 2009); Elizabeth Philips, Political Theology: A Guide for the Perplexed (New York: Bloomsbury, 2012). In addition, there is a book series at Columbia University on political theology.

52 Wariboko, Nigerian Pentecostalism, 204-205.

53 Ibid., 167. 
symbolic structure (norms, practices, texts, routines)" allowing a retextualization and renormalization of sociality. Marshall focuses on the juridico-political and a rule-governed sovereignty. One cannot doubt that Pentecostal practices offer ethical ideals for political theory and practice to counterbalance "norms, practices, texts, [and] routines", and that such a counterbalancing indeed retextualizes society; but in terms of political discourse and practice, one wonders if it normalizes political practice, if by normalize we mean returning to a functioning polis that works for the common good that would embrace all member of the political community without insisting on a theological norm which others may find problematic. One cannot question the emphasis that Wariboko places on ethics in his numerous writings and one must also agree that he is correct that deploying virtues and moral practices within Pentecostalism which he analyzes through the virtue of friendship has a revolutionary impact on morality and politics in Africa today. However, some would contest the case he has made because it remains an internal ethic that is grounded on another sovereign, the Spirit of God. While one cannot restrict a religious community from demonstrating its ethical impulse, one wonders if in the case of Pentecostalism it is chastened by the respect for difference or even the rejection of the Pentecostal ethos by other Christian communities. To put it more crudely, is the direct application of a theology that promotes the presence, and power of the Holy Spirit and miracles that believers should expect and live by, a hindrance to the emergence of genuine political sovereignty? I think it is.

In the next section, I propose a reinterpretation of the notion of sovereignty as a way of rethinking political theology, a project that can only succeed if there is a dialogue between theology and the social sciences.

\section{5}

\section{Rethinking Sovereignty in Political Theology}

I am convinced that social scientific theories offer ways of expanding the notion of sovereignty beyond the idea of the "One" which refers to the head of the political community alone. While conceding that the "One" makes decisions even outside the law, I should note that Schmitt made an amazing revelation by affirming that

all tendencies of modern constitutional development point toward eliminating the sovereign in this sense ... But whether this extreme exception can be banished from the world is not a juristic question. Whether one has confidence and hope that it can be eliminated depends on 
philosophical, especially on philosophical-historical or metaphysical convictions. ${ }^{54}$

Therefore, a better way of thinking about sovereignty is to shift it from Schmitt's focus on an individual leader who is all powerful. Instead, sovereignty is inscribed in the constitution, in laws enacted by elected representatives of the people, and the other legal instruments without which sovereignty is incomplete. Since democracy is the rule of the people, sovereignty belongs to the people. In many African countries, that process is grounded in the constitution that spells out the political institutions and lays out the structures of governing authorities and how those who govern are selected. The constitution and laws provide for a judicial system that regulates, sanctions, or disciplines the practices of the state and its citizens. In principle, those who govern work with the elected representatives of the people (in the House of Assembly, Parliament, or senate) to create further institutions that would facilitate governance and enable those who govern to fulfill their obligations to the people, and promote equality, liberty, and justice. A blanket refutation of the notion of sovereignty misses the broad institutional and juridical advantages embedded in the idea of sovereignty as I discuss it here. The constitutional and juridical implications are important because legal provisions and structures offer the means of checking the absolutism of sovereignty if we insist on limiting sovereignty to the "one."

Therefore, given this perspective, I would argue that one can appreciate sovereignty in the manner political theologians have discussed if one considers four further descriptors. First, sovereignty is a foundational and generative ideal and praxis. It certainly derives from the will of the people to co-exist in a political community. One could explore and understand this from the tradition of political philosophy that has stressed the rule of the demos, in classical times, or its modern versions which postulate the political community in Hobbesian terms which state that people come together to form a political community as a way of dealing with human proclivities. One could also understand this through a social contract model perhaps best illustrated by the enduring American political phrase "we the people." My argument is that, in all of these approaches, the notion of sovereignty is generative and points to the founding and reproduction of politics and the political community as normative praxis subject to the will of the people. There is no doubt that those foundations - for example, in ancient Egyptian, Greece, and African kingdoms

Schmitt, The Concept of the Political, 5-7. 
like the Yoruba, the Buganda, the Zulu, and Great Zimbabwe which were colonized and liberated into the post-neocolonial state ${ }^{55}$ whose arrangements still exist today - may have had mythic and religious roots. But one must insist that what has emerged is a political community where modern political thought holds that those who govern do so better if they govern with the consent of the people. Sovereignty as a generative process then, is a deliberate and thoughtful process which requires that the architecture on which the idea of a nation is constructed draws from the best and most enduring values of humanity and each community. We can debate what those values are but it seems clear that, to most observers, they include life and wellbeing, liberty, freedom, and justice to enable the furtherance of the common good.

Sovereignty of the people, therefore, has foundational qualities that need solid grounds, which, in many cases, are the constitution and institutions of a country. The philosophical, political, economic, and social basis for instruments that ground sovereignty, like a constitution and institutions, must provide it with enduring values to shield it from political and, especially, theological manipulation. Statehood in many parts of Africa during the half century since independence has been marked by the violent manipulation of those instruments of sovereignty by politicians and dictators who have amended, ignored, or suspended their constitutions to stay in power, destabilizing many African countries and destroying the notion of sovereignty.

Second, it follows that sovereignty must be linked to viable national and regional institutions. The constitution must be adopted by the representatives of the people, who also propose, debate, and pass laws and work within certain institutions such as the Presidency, the legislature, the judicial system, and state, and municipal offices. Institutions are normative enclaves because they have rules of engagement and the regulations that stipulate the different bureaucratic processes necessary to maintain a functioning political community. Those rules make it possible for all members of the political community to be subjected to the requirements of the law and the processes of good governance. Hence, members of the legislature can be sanctioned or impeached for ethical violations demonstrating that no one is above the law. Religious groups may condemn those ethical violations, but in the main, the regulations are not religious ideas but legal instruments that deal with public and political conduct and social practices appertaining to the offices to which individuals have been elected, or hired to serve. These institutions are dynamic and adaptive to the needs of the time.

55 The term postneocolonial, is used intentionally to emphasize colonialism and neocolonialism. 
One must therefore recognize and accept the reality that political institutions have their own ethic.

Religious communities, on the other hand, comprise different types of institutions that offer a variety of services to the political community. Some of these services - spiritual, emotional, and psychological wellbeing, health care, and education in the African context - have been crucial for the intellectual, social, and economic development of many African countries. Together, religious institutions have helped define the post-neocolonial state, even though they have had their own problems because some leaders of religious institutions have engaged in corrupt practices themselves. ${ }^{56}$ While I insist on the notion of sovereignty vested in the people and supported by an institutional framework adopted by the people, Wariboko thinks that the Pentecostal perspective introduces ethical practices that could enable individuals have a positive impact on institutions. He argues: "my overall argument focuses on practices, institutions, and structures that can sustain the ideas of sovereignty and community. ${ }^{17}$ My perspective is that political institutions concerned with the governance and sustainability of the state remain the primary theatre of activity and any political theology ought to recognize this reality because those institutions are what make the people sovereign, not religious communities, regardless of the important role the latter have played in the post-neocolonial state.

Third, it follows from what I have said in the previous section that this configuration of sovereignty moves away from sectarian religious perspectives. I use the word sectarian broadly here, to refer to all religious communities. One of the truisms of the sociology of religion during the last two decades has been the recognition that the so-called secularization of society did not materialize because religion has remained a dominant social force. This is true of Western democracies as well as Africa where the church, strengthened by the Pentecostal revival, is experiencing phenomenal growth. However, that does not change the fact that many countries in the world are by nature secular states, not theocracies. Therefore, what is needed for political theology is a rigorous and negotiated vision of the secular, which recognizes a realm defined by a social contract that is broad enough to tolerate and encourage dialogue with other views, but refrains from constraining those visions as long as they do not interfere with the "pursuit of life, liberty, and justice." In other words, sovereignty of the people works best when we guarantee secularity that is loosely defined but

$5^{6}$ Paul Gifford, African Christianity: its Public Role (Bloomington: Indiana University Press, 1998).

57 Wariboko, Nigerian Pentecostalism, 170. 
allows for religious beliefs and practices that do not dominate or offer a limited exclusionary view of the world and political community. This, in principle, is the way religious communities relate to political communities, but in many African countries religion has taken center stage and political leaders have acted as if they live in a theocracy, or at least been given a mandate to govern by God. ${ }^{58} \mathrm{~A}$ broad view of the secular allows room for religion, belief, faith, and a morality inspired by those beliefs, yet recognizes that the secular serves as a neutral ground for contested spiritualities that must be deployed in a sphere where sovereignty is not that of a divine being, but the sovereignty of the people.

Given this perspective, many would partially agree with Wariboko's project which stresses "raising issues ... from the interior of the Pentecostal worldview and social practices and mutually correlating them with answers from nuanced philosophical interpretations of the notions of community, sovereignty, and miracles," something he argues Marshall fails to achieve. ${ }^{59}$ Here, I think Marshall, or anyone who recognizes the specificity of the Pentecostal argument or worldview, has no problem, provided the notion is not rejected that such a perspective can be used in dialogue with, or to contest, philosophical and theological perspectives articulated in Western political theology. In addition, community and polity inspired by ecclesial bodies or religious communities are important, but such polity must not be allowed to dictate sovereignty as I have narrowly defined it here. Wariboko cites John Milbank who argues that,

for a polity based on virtue, the goal of authority is not simply an effective peace and order, nor the representation of ... majority will, nor the liberty and equality of individuals, but rather the education of individuals into certain practices and states of character, regarded as objectively desirable goals for human beings as such. ${ }^{60}$

I must point out that my view differs in that both Milbank and Wariboko describe ethical practices that function within institutional contexts that have a rich democratic practice. However, for post-neocolonial Africa, the recovery of

$5^{8}$ Patrick Claffey, "Kérékou the Chameleon, Master of Myth," in Staging Politics: Power and Performance in Asia and Africa, eds. Julia C. Strauss and Donald B. Cruise (London: I.B. Tauris, 2007), 98-101; See also Patrick Claffey, Christian Churches in Dahomey-Benin: A Study of their Socio-Political Role, (Leiden: Brill, 2007), $114 \mathrm{ff}$.

59 Wariboko, Nigerian Pentecostalism, 170.

6o John Milbank, Theology and Social Theory: Beyond Secular Reason (Malden, MA: Blackwell, 1990), 326. 
the social, the political, and the very idea of a community and polis, needs a democratic base with a broad secular vision where religious beliefs are not only tolerated, but also deployed to promote a pluralistic vision for all members of the political community. Making room for such a religious-ethical approach to the common good requires a fourth and final dimension of sovereignty.

This involves acknowledgment that sovereignty of the people is a rational process. Wariboko rightly reminds us of the dangers of the "religion of reason" as exhibited by the excesses of the French Revolution, and argues that the current Pentecostalism revolution or "religion of virtues" promotes the common good and a human telos. The good life in this context means one is saved (one lives in Christ) and belongs to the eschatological community and the reign of God. ${ }^{61}$ Regarding the good life, I should point out that one cannot fault Wariboko for insisting that sovereignty requires techniques of the self that promote discipline and virtues in the Socratic tradition (and, we should add, in African virtues of community). ${ }^{62}$ But I must insist that stressing the secular version of sovereignty does not necessarily call on Pentecostals to abandon being who they are spiritually, as long as that spirituality does not engender exclusivist views and practices that can disrupt the political community by silencing other views or supporting dictatorial and corrupt tendencies in politicians who profess to be born again believers, attend Pentecostal rallies, or take unilateral actions to make their countries "Christian nations." ${ }^{33}$ One hardly needs to raise the example of President Chiluba of Zambia - a self-professed Pentecostal who declared his country a Christian nation and frequently visited Prophet T.B. Joshua - who was later charged with corruption, though acquitted after a trial. ${ }^{64}$ One therefore must insist that what some Pentecostals offer at this point is a privatized ethic and morality designed to serve as the "salt and light of the earth" but there is no guarantee that it can effect a social political revolution without the secular dimensions of sovereignty.

Wariboko has addressed this subject in The Pentecostal Principle, offering further illuminating ideas in The Charismatic City and the Public Resurgence of

$61 \quad$ Wariboko, Nigerian Pentecostalism, 172.

62 Plato, "Alcibiades," in Plato: Complete Works, ed. John M. Cooper (Indianapolis, IN: Hackett, 1997), 557-595. Citation in Wariboko, Nigerian Pentecostalism.

63 Isabel Apawo Phiri, "President Frederick Chiluba and Zambia: Evangelicals and Democracy in a 'Christian Nation," in Evangelical Christianity and Democracy in Africa, ed. Terence O. Ranger (Oxford: Oxford University Press, 2001), 95-129. See also Gifford, African Christianity.

64 "Zambia ex-president Chiluba acquitted of graft," accessed March 13, 2016, http://www. reuters.com/article/us-zambia-corruption-chiluba-idUSTRE $57 \mathrm{G}_{3} \mathrm{~N}_{320090817}$ 
Religion, and argues that sovereignty is also a performative term, insisting that the community guarantees sovereignty, a perspective with which one would agree. He points out that since sovereignty also includes "ideals of control and domination and performance of political norms, then new ways of constructing it are possible," and one would have to say such a position recognizes the dynamics of political ideals and practice in different contexts. ${ }^{65}$ However, Wariboko insists that the Pentecostal performance has the power to produce the sovereignty it performs. Asserting that one way to understand sovereignty is to see it as an empty space that needs to be filled, Wariboko acknowledges that the sovereignty of virtues is weak. It emerges from, and functions within, a limited spiritual context. It is for that reason that Wariboko's position is problematic because he goes on to argue that Pentecostal spirituality is not about "institutional design for societal decision or control but what kind of a person or people Pentecostals will [want to] be."66 He develops this point further by drawing on virtue and character, a move that no one can deny has an important place in the political community. His argument that the Redeemed Christian Church of God, North American division, that has created a legacy week during which people develop a narrative of their collective relationship and interactions in Christ, a project he sees as a new political practice in Pentecostalism, is not strong enough. Finally, Wariboko argues that this community must embody an institutional form (one assumes a Pentecostal ecclesial and ethical framework) that must reflect, in Hauerwasian terms, the community's own self-understanding.

Every discussion of the ethics of virtue requires a fair hearing, but I must insist that a broad understanding of sovereignty ought to be rational. This position has nothing to do with whether the Pentecostal worldview creates a community that offers an ethic that could affect the political community or not. What remains worrisome for me is the lack of rationality involved in practices grounded on miracles that has marked Pentecostal beliefs, discourses, deliverances, and the all too often uncritical critique that African ancestral cultures hinder the opening of the doors of economic opportunities for African Christians to have wealth. To be fair to Wariboko, he is not seeking to demonstrate that miracles can be translated into broad public policy solutions. There is also no doubt that, under certain circumstances, one could find "the ideal person in Nigerian Pentecostalism [who] is fast becoming the autonomous, self-sufficient, free person." ${ }^{67}$ One wonders if this is not a rather strong claim to make in a

\footnotetext{
65 Wariboko, Nigerian Pentecostalism, 179.

66 Ibid., 182.

67 Ibid., 185 .
} 
context where people lay a lot of emphasis on power relations, especially the power of the "pastor" who now wields a lot of power in the private and public lives of the people. Wariboko states this "ideal" person is self-sufficient and owes no debts to the past and the future because God and the Holy Spirit will always guide the believer to the things he or she needs to consume (and, here, I do not quarrel with a consumer economy). It is also not revelatory to read that a relationship between Pentecostals and God is not love and sacrifice but a contract, which requires virtues to build a new community, since that has always been part of the broad ecclesial vision.

What I question is the rationality of the economy of miracles. Wariboko argues that miracles are ways for the community to control the possibilities available to them and "speak of surplus possibilities beyond what a community (polity) may understand and control"; the demand for miracles, then, is "a call to defend, control, and embody the excess possibilities." ${ }^{68}$ But, more importantly, miracles disrupt control and domination, especially of the sovereign political ruler. One must point out here that some Pentecostal leaders have been very dominant persons and leaders in the churches. Wariboko's argument underscores the view that miracles embrace a community that works on virtue and creates a community in which consent is given by individuals to the larger goals of the community.

Wariboko rightly points out that intellectual discourses on miracles point to their role in destabilizing institutionalized authority. He then describes miracles as exceptional events that create a new situation without suspending or transgressing laws and, more importantly, open new possibilities. Miracles depend on the sovereign God and the person who experiences a miracle, the believer who depends on faith alone. Miracles are discourses which can be seen in the testimonies given by believers. Miracles in this context may not be real, but demarcate excess and signal new possibilities or a form of dream and creates "a full jouissance beyond the law." ${ }^{69}$ Miracles are performatives which rupture reality in temporal spaces. The miraculous overflows through the cracks because the sacred represents excess that overflows all possibilities because of the grace of God. Finally, Wariboko argues that miracles, then, are a form of capitalism. The activity of miracles is connected by the visible and invisible realms where the social practice of spirituality is mediated by miracles that fracture the sacred veil and connects the two realms and produces specific

68 Wariboko, Nigerian Pentecostalism, 185.

69 See Slavoj Žižek, "Neighbors and Other Monsters: A plea for Ethical Violence," in The Neighbor: Three Inquiries in Political Theology, eds. Slavoj Žižek, Eric Santner, and Kenneth Reinhard (Chicago: University of Chicago Press, 2006), $134 \mathrm{ff.}$ 
goods in a context where "the real is about saving and possessing. This is what it means to have treasure both in heaven and on earth." ${ }^{70}$ Drawing from Slavoj Žižek, Wariboko compares this interface of spirituality, transcendence, and the enjoyment of these earthly pleasures to the spirit of late capitalism. But the point here is that Wariboko sees nothing in miracles that prevents the building of a political order; if anything, miracles contribute to and should be an important component of reviving the economy and restoring political order in Africa. Other communities of discourse can also join practices which embody miracles, because they are expressions of an ontological spirituality which have been carried over from African traditional religions.

My concern with this focus on miracles is that its reinterpretation highlights anticipation and gives individuals grounds for hope but the claims that it does not dispense with the law are not correct if we see the law as a body of legal instruments that embody the broad normative context in which political decisions and economic regulations have to be made. We can even argue here that "law" could refer to well tested, precedent-setting ideas, norms, and practices that has enabled generations build strong political economies. Miracles do not offer a stable grounding for public policy that can promote measurable goals. There is no doubt that Pentecostal testimonies speak about successes which the individual did not anticipate, but if you listen to many of them, the narrative also includes the practice of virtue which Wariboko articulates very well; this may include hard work, diligence in one's studies, the practices of thrift and saving, and self-discipline that involves a complete turnaround from waste to constructive behavior, all in a social and institutional context without which miracles would hang in the air or to put it more crudely, make no sense. Therefore, to restructure the public square on miracles cannot work for economy like that of Nigeria or other African countries because, as a project, it lacks the rational elements that are necessary to coordinate a broad national economic policy; miracles, therefore, cannot be translated into broad social policy.

In the final section of this chapter, I discuss the necessity for a dialectical approach to a political theology of sovereignty to round up the theme of this chapter that calls for a dialogue between theology and the social sciences.

\section{Towards a Critical Dialectical Political Theology of Sovereignty}

What I call for is a dialectical approach which recognizes that the social sciences offer tools with which, as theologians, we can deepen our understanding

70 Wariboko, Nigerian Pentecostalism, 196-197. 
of political philosophy, policy, institutions, governance, the political economy, and address corruption, gender discrimination, and human rights abuses. Such a political theology cannot ignore the social theatre of politics, which is often mapped out in social science literature. Therefore, a dialectical political theology must draw from all the sciences to rethink the notion of sovereignty, which I have argued should refer in a broad sense to constitutional and legal authority over a people, or a political jurisdiction..$^{71}$

My understanding of sovereignty is guided by modern political developments that strip away absolutist control by political leaders and reject the notion of the divine rights of kings. ${ }^{72}$ It stresses ideals that Jean-Jacques Rousseau contributed to political philosophy by introducing the notion of a social contract that Rousseau defined as a nontransferable general will that was infallible and could be limited only by common interests. Such sovereignty should be grounded in the legal instruments (proposed by lawmakers) and structure of the political community, instruments that, I should add, are not lacking in Africa. ${ }^{73}$ John Stuart Mills, who argued that every individual is a sovereign, would formulate the ultimate perspective on sovereignty. There are broad issues here which I cannot exhaust, such as limitation of power, independence, and international implications of sovereignty, but we need an interdisciplinary approach for a political theology that is vibrant in the African context to capture the many essential elements of politics and theology. Such a dialectical approach should exceed Schmitt's view that a "[s]overeign is he who decides on the exception [and] all significant concepts of the modern theory of the state are secularized theological concepts." ${ }^{74}$ This last section of Schmitt's view must be contested because it grants a special privilege to theology in the formulation of political philosophy. It should be supplemented with the multidisciplinary

$71 \quad$ I am indebted to Dan Philpott, "Sovereignty" in Stanford Encyclopedia of Philosophy, accessed July 25, 2013. See also Dan Philpott, Revolutions in Sovereignty: How Ideas Shaped Modern International Relations (Princeton: Princeton University Press, 2001); Stephen D. Krasner, Problematic Sovereignty: Contested Rules and Political Possibilities, (New York: Columbia University Press, 2001); Thomas Biersteker and Cynthia Weber, State Sovereignty as Social Construct (Cambridge: Cambridge University Press, 1996); Emmanuel Wallerstein, World Systems Analysis: An Introduction (Durham, NC: Duke University Press, 2004).

72 Jean Bodin, On Sovereignty: Four Chapters from Six Books of the Commonwealth (Cambridge: Cambridge University Press, 1992). See also Thomas Hobbes, Leviathan (Harmondsworth, UK: Penguin Books, 1968). Hobbes thought that the governed could resist domination by forming a new commonwealth to force the sovereign live up to their expectations.

73 Jean-Jacques Rousseau, The Social Contract, (New York: Penguin Books, 2012)

74 Carl Schmitt, Political Theology: Four Chapters on the Concept of Sovereignty, trans. George Schwab (Chicago: University of Chicago Press, 2005), p. 5-35. 
and dialectical approach that I am advocating because, for better or worse, a wider theoretical grounding of political thought and practice lies with Thomas Hobbes' notion of a social contract, which rejects or significantly reduces the concentration of power in one individual and privileges broad legal instruments and institutions that establish politics as an interdependent human and social practice. ${ }^{75} \mathrm{~A}$ viable political theology does not need to depend on Schmitt alone but, rather, seek to move beyond his Weimar Republic perspective, as Paul Kahn has rightly suggested. ${ }^{76}$

In the African context, the drama of the post-neocolonial state or the postcolony has been studied from different disciplinary angles, including that of theology. ${ }^{77}$ However, after the fury over the reforms proposed by the World Bank and the International Monetary Fund through the (in)famous Structural Adjustment Program, it is necessary, in an exercise of realignment of sovereignty, to rethink political theology in the African context as people power. Rethinking political theology calls for a reexamination of the lives of ordinary individuals, the governed, who themselves are not only affected by the acts of sovereigns, but could be key actors in the game of politics. It is important to redirect political theology towards the examination of some of the major players in political action in the context: the rise of private, non-governmental organizations and the sustainability of their work. Finally, it is important to reexamine political theology in the African context because it is crucial to examine the role of women in African society.

For many people the idea of political theology is a modern intellectual enterprise that analyzes the state, its institutions, and its governance, but one that has turned into what Mark Lilla describes as a mismanaged liberal project. ${ }^{78}$ My own perspective is informed by liberal Protestant thinking that has argued that the sacred traditions of Christianity and Jewish prophetic thought demonstrate a close relationship between the state and religion. Modern political thought provides a liberative perspective by postulating a separation of powers without ruling out the grounds on which people of faith can make

75 Thomas Hobbes, Leviathan (Oxford: Clarendon Press, 2012).

76 Paul W. Kahn, Political Theology: Four New Chapters on the Concept of Sovereignty (New York: Columbia University Press, 2012), 5. See Peter Caldwell, Popular Sovereignty and the Crisis of German Constitutional Law: The Theory and Practice of Weimer Constitutionalism (Durham, NC: Duke University Press, 1997); Ellen Kennedy, Constitutional Failure: Carl Schmitt in Weimar (Durham, NC: Duke University Press, 2004); Gopal Balakrishnan, The Enemy: An Intellectual Portrait of Carl Schmitt (New York: Verso Press, 2002).

77 Bongmba, Dialectics of Transformation in Africa.

78 Mark Lilla, The Stillborn God: Religion, Politics and the Modern West (New York: Vintage, 2007). 
claims about the responsibility of the state to the members of the commonwealth, understood in light of the social contract, which is largely a human construct that does not need divine sanction to be effective. The emphasis, then, is on the notion that people have mutually agreed to adopt a set of legal instruments that would be the standard for regulating the vision and activity of the political community. Such legal instruments and the institutions are open to scrutiny from all ideological positions.

The social contract as understood by other disciplines introduces liberative and reconstructive dimensions which have, and should, shape African political theology, precisely on the grounds that those who hold and exercise power in a commonwealth are invited to lead and shape the vision of the political community as it strives in different ways to keep and execute a social contract that is amendable to the common good. It is in this context that a dialectical approach to political theology must continue to examine institutions and structures as aspects of sovereignty broadly defined, whether those who conduct such examination draw from the Magisterium, or the rich Protestant intellectual tradition, or normative philosophical and ethical perspectives. In the North American context, some of the things that, one could argue, have limited sovereign exclusivity, such as judicial review of legislative actions and those of the executive branch, are actually things that ultimately strengthen sovereignty because such checks and balances place limits on the extraneous reach of political leaders who may use their religious and theological beliefs to constrain the effective search for the common good. ${ }^{79}$ In some countries, this provision is not available. A good example here is the idea of the presidential decree in Cameroon. In jurisprudence, a decree refers to a decision that is arrived at in a court of equity and is tantamount to judgment, except that the process of arriving at a decree allows room for the consideration of the rights of both parties to an issue, and a decree may stipulate what is necessary or needed from the parties involved, the conditions for its execution, or what both parties have to do to enforce the decree. Political decrees may supposedly uphold the constitution of a country and its existing laws but, in the context of Cameroon, a presidential decree is the ultimate expression of sovereignty in the limited sense of the powers of the single ruler because it is the mechanism through which the president governs and makes all appointments from the lowest government officer to the highest government officer including the prime minister. The only person the president does not appoint by presidential decree is the president himself. 
Thus, a political theology in the African context still needs to pay attention to institutions and their actors as way of shifting and expanding the notion of sovereignty from its specific focus on the executive branch of government to include the legislative and judiciary since that would be a fuller and richer expression of sovereignty. In such a context, the use of miracles by people to effect political change (although miracles remain a legitimate function and aspect of faith) will be redundant as the grounds for concrete political change and transformation.

\section{References}

Balakrishnan, Gopal. The Enemy: An Intellectual Portrait of Carl Schmitt. New York: Verso Press, 2002.

Bates, Robert, V.Y. Mudimbe, and Jean O'Barr. Africa and the Disciplines: Contributions of Research in Africa to the Social Sciences and Humanities. Chicago: University of Chicago Press, 1993.

Biersteker, Thomas and Cynthia Weber. State Sovereignty as Social Construct. Cambridge: Cambridge University Press, 1996.

Bodin, Jean. On Sovereignty: Four Chapters from Six Books of the Commonwealth. Cambridge: Cambridge University Press, 1992.

Bongmba, Elias K. "Lament and Narrative: A Review of Emmanuel Katongole's The Sacrifice of Africa." Modern Theology 30, no. 2 (2014): 403-407

Bongmba, Elias K. "Interdisciplinary and Transdisciplinarity in African Studies." Religion and Theology 21, no. 3-4 (2014): 218-25.

Bongmba, Elias K. Facing a Pandemic: The African Church and Crisis of AIDS. Waco: Baylor University Press, 2007.

Bongmba, Elias K. The Dialectics of Transformation in Africa. New York: Palgrave Macmillan, 2006.

Caldwell, Peter. Popular Sovereignty and the Crisis of German Constitutional Law: The Theory and Practice of Weimer Constitutionalism. Durham, NC: Duke University Press, 1997.

Claffey, Patrick. "Kérékou the Chameleon, Master of Myth." In Staging Politics: Power and Performance in Asia and Africa edited by Julia C. Strauss and Donald B. Cruise, 98-101. London: I.B. Tauris, 2007.

Claffey, Patrick. Christian Churches in Dahomey-Benin: A Study of their Socio-Political Role. Leiden: Brill, 2007.

Fabian, Johannes. Time and the Other: How Anthropology Makes its Object. New York: Columbia University Press, 1983.

Ferguson, James. Global Shadows: Africa in the Neoliberal World Order. Durham, NC: Duke University Press, 2006. 
Fontana, Andrea. “The Interview: From Structured Questions to Negotiated Text.” In Handbook of Qualitative Research, edited by Norman K. Denzin and Yvonna S. Lincoln, Los Angeles: Sage Publishers, 2005.

Gifford, Paul. African Christianity: its Public Role. Bloomington: Indiana University Press, 1998.

Hagmann, Tobias and Didier Pélcard, eds. Negotiating Statehood: Dynamics of Power and Domination in Africa. Malden, MA: Wiley Blackwell, 2010.

Hobbes, Thomas. Leviathan. Harmondsworth, UK: Penguin Books, 1968.

John Paul II, Ecclesia in Africa (Post Synodical Apostolic Exhortation). Nairobi: Paulines Publications, 1995.

Kahn, Paul W. Political Theology: Four New Chapters on the Concept of Sovereignty. New York: Columbia University Press, 2012.

Kalu, Ogbu U. African Pentecostalism. Oxford: Oxford University Press, 1998.

Katongole, Emmanuel. The Sacrifice of Africa: A Political Theology for Africa. Grand Rapids: William B. Eerdmans Publishing Company, 2011.

Katongole, Emmanuel. Born From Lament: The Theology and Politics of Hope in Africa. Grand Rapids: William B. Eerdmans, 2017.

Kee, Alister ed. The Scope of Political Theology. London: SCM Press, 1978.

Kee, Alister, ed. A Reader in Political Theology. London: SCM, 1977.

Kennedy, Ellen. Constitutional Failure: Carl Schmitt in Weimar. Durhan, NC: Duke University Press, 2004.

Kirwin, Michael. Political Theology: An Introduction. Minneapolis: Fortress Press, 2009.

Krasner, Stephen D. Problematic Sovereignty: Contested Rules and Political Possibilities. New York: Columbia University Press, 2001.

Lilla, Mark. The Stillborn God:Religion, Politics and the Modern West. New York: Vintage, 2007.

Magesa, Laurenti. "African Christian Spirituality." In African Theology on the Way: Current Conversations, edited by Diane Stinton, 68-78. London: SPCK, 2010.

Makkreel, Rudolf A. and Frithjof Rodei, eds. Wilhem Dilthey: Selected Works Volume 1: Introduction to the Human Sciences. Princeton: Princeton University Press, 1991.

Maritain, Jacques. Man and State. Chicago: University of Chicago Press, 1951.

Marshall, Ruth. Political Spiritualties: The Pentecostal Revolution in Nigeria. Chicago: University of Chicago Press, 2009.

Marshall-Fratani, Ruth. "Mediating the Global and Local in Nigerian Pentecostalism." Journal of Religion in Africa 28, no. 3 (1998): 278-315.

Mbembe, Achille. "Necropolitics." Public Culture 15, no. 1 (2003), 11-40.

Meier, Heinrich. Carl Schmitt and Leo Strauss: The Hidden Dialogue. Translated by J. Harvey Lomaz. Chicago: University of Chicago Press, 1995.

Metz, Johann Baptist. Theology of the World. New York: Seabury Press, 1973.

Milbank, John. Theology and Social Theory: Beyond Secular Reason. Malden, MA: Blackwell, 1990. 
Mudimbe, V.Y. The Idea of Africa. Bloomington: Indiana University Press, 1994.

Mudimbe, V.Y. The Invention of Africa: Gnosis, Philosophy, and the Order of Knowledge. Bloomington: Indiana University Press, 1988.

Nyamiti, Charles. Some Contemporary Models of African Ecclesiology: A Critical Assessment in the Light of Biblical and Church Teaching, Studies in African Christian Theology, Vol 3. Nairobi: Catholic University of East Africa, 2007.

Orobator, Agbonkhianmeghe E. "Contextual Theological Methodologies." In African Theology on the Way: Current Conversations, edited by Diane Stinton, 3-11. London: SPCK, 2010.

Orobator, Abongkhiameghe E. From Crisis to Kairos: The Mission of the Church in the Time of HIV/AIDS, Refugees and Poverty. Nairobi: Pauliness Publications, 2005.

Philips, Elizabeth. Political Theology: A Guide for the Perplexed. New York: Bloomsbury, 2012.

Philpott, Dan. Revolutions in Sovereignty: How Ideas Shaped Modern International Relations. Princeton: Princeton University Press, 2001.

Phiri, Isabel Apawo. "President Frederick Chiluba and Zambia: Evangelicals and Democracy in a 'Christian Nation,' In Evangelical Christianity and Democracy in Africa, edited by Terence O. Ranger, 95-129. Oxford: Oxford University Press, 2001.

Plato. “Alcibiades." In Plato: Complete Works, edited by John M. Cooper, 557-595. Indianapolis: Hackett, 1997.

Reuters. "Zambia ex-president Chiluba acquitted of graft." Accessed March 13, 2016. http://www.reuters.com/article/us-zambia-corruption-chiluba-idUSTRE $57 \mathrm{G}_{3} \mathrm{~N}_{3}$ 20090817

Rousseau, Jean-Jacques. The Social Contract. New York: Penguin Books, 2012.

Scherz, China. Having People, Having Heart: Charity, Sustainable Development, and Problems of Dependence in Central Uganda. Chicago: University of Chicago Press, 2014.

Schmitt, Carl. The Concept of the Political, Chicago: University of Chicago Press, 1996.

Schmitt, Carl. Political Theology: Four Chapters on the Concept of Sovereignty. Translated by George Schwab, 5, 35. Chicago: University of Chicago Press, 2005.

Scott, Peter and Willian T. Cavanaugh. The Blackwell Companion to Political Theology. Malden, MA: Wiley-Blackwell, 2006.

Tillich, Paul. The Protestant Era. Chicago: University of Chicago Press, 1948.

Vansina, Jan. Living with Africa. Madison: The University of Wisconsin Press, 1994.

de Vries, Hent and Lawrence E. Sullivan. Political Theologies: Public Religions in a PostSecular World. New York: Fordham University Press, 2006.

Wallerstein, Emmanuel. World Systems Analysis: An Introduction. Durham, NC: Duke University Press, 2004. 
Wariboko, Nimi. Nigerian Pentecostalism. Rochester: University of Rochester Press, 2014.

Žižek, Slavoj. "Neighbors and Other Monsters: A plea for Ethical Violence." In The Neighbor: Three Inquiries in Political Theology, edited by Slavoj Žižek, Eric Santner, and Kenneth Reinhard. Chicago: University of Chicago Press, 2006. 
Elias Kifon Bongmba - 9789004412255 Downloaded from Brill.come4/26/2023 03:13:12PM via free access 